Nloman 2020, 38(1), 75-86

Revista de Psicologia, Ciències de l'Eduació i de l'Esport

ISSN: $1138-3194$

CFacultat de Psicologia, Ciències de l'Educació i de l'Esport Blanquerna

Universitat Ramon Llull

(c) (1)

\title{
What do pre-service teachers know about computational thinking?
}

\author{
Marta Peracaula-Bosch ${ }^{1}$, Meritxell Estebanell-Minguell ${ }^{1}$, Digna Couso ${ }^{2}$ \\ \& Juan González-Martínez ${ }^{1}$ \\ 1 Universitat de Girona \\ 2Universitat Autònoma de Barcelona
}

Received: 2019-10-27

Accepted: 2020-4-23

\section{What do pre-service teachers know on computational thinking?}

Summary. In recent years, interest in Computational Thinking (CT), which is seen as a transversal competence that is necessary in the Knowledge Society, has spread to educational systems around the world. In this context, it has become necessary for training programmes for pre-service teachers to address this topic. In this article, we explore the knowledge, attitudes and expectations regarding CT held by pre-service teachers, prior to receiving training on this field. We use a descriptive analysis of both qualitative and quantitative data obtained via an ad hoc questionnaire, whereby 193 pre-service teachers at the University of Girona were asked about different aspects related to CT. The study shows that the majority of pre-service teachers cannot correctly identify most indicators associated to CT, and that most of them are unaware of the implications of the promotion of CT in terms of developed skills or areas of application. However, their expectations regarding their learning process with regard to this topic are positive. Therefore, it is necessary to more thoroughly define theoretical foundations of the concept in order to take steps to effectively include it in teacher training programmes.

Keywords: computational thinking; pre-service teachers; teacher training; ICTs; skills

Què saben els mestres en formació inicial sobre el pensament computacional?

Resum. En els últims anys, l'interès en el pensament computacional (PC), considerada una competència transversal necessària en la Societat de el Coneixement, s'ha estès als sistemes educatius de tot el món. En aquest context, ha esdevingut necessària la introducció i capacitació en el desenvolupament del PC en els programes de formació inicial de mestres. En aquest estudi, s'explora el coneixement, les actituds i les expectatives pel que fa al $P C$ que tenen els mestres en formació inicial, abans de rebre capacitació en aquest camp. Utilitzem una anàlisi descriptiva de les dades qualitatives i quantitatives obtingudes a través d'un qüestionari ad hoc, mitjançant el qual es va preguntar a 193 docents en formació de la Universitat de Girona sobre diferents aspectes relacionats amb el $P C$. L'estudi mostra que la majoria dels estudiants de magisteri enquestats no poden identificar correctament molts dels indicadors associats amb PC, i que la majoria d'ells desconeixen les implicacions de la incentivació del PC en termes d'habilitats desenvolupades o àrees d'aplicació. No obstant això, les seves expectatives pel que fa al seu procés d'aprenentatge en aquest tema són positives. Per tant, cal definir més a fons els fonaments teòrics del concepte per tal de prendre mesures per incloure'l de manera efectiva en els programes de capacitació docent.

Paraules clau: pensament computacional; formació inicial de magisteri; magisteri; TIC; competències

\author{
Correspondence \\ Marta Peracaula-Bosch \\ https://orcid.org/0000-0003-0871-6583 \\ Serra-Hunter Fellow. Departament de Pedagogia. Institut de \\ Recerca Educativa. Universitat de Girona. \\ Plaça de Sant Domènec, 9. 17004 Girona (Spain). \\ email: marta.peracaula@udg.edu
}




\section{Introduction}

\section{Computational thinking in education}

In the last decade, the concept of Computational Thinking (hereinafter, CT) has gained prominence as one of the skills that can help citizens to manage the complex situations that characterize our Knowledge Society (KS). The new challenges that the KS poses force us reconsider the learning needs of $21^{\text {st }}$ century citizens, all of whom will inevitably live in the context marked by VUCA (the initials for Volatility, Uncertainty, Complexity and Ambiguity) (Acevedo Borrega, 2016). This context forms the backdrop for Wing's (2006)'s reflection on CT. She advocates for the embrace of CT as a basic, transversal tool in the curriculum, one that will allow to learn in an abstract, algorithmic, logical way and, as such, will prepare them to solve complex, open problems.

A number of other authors have echoed this idea, arguing that CT is a basic skill for $21^{\text {st }}$ century citizens (Angeli et al., 2016; European Commission/EACEA/ Eurydice, 2012; Fluck et al., 2016). Educational programmes aimed at CT seek to empower individuals to carry out effective problem-solving procedures and to redefine the relationship between the learner and the topics she learns, beyond CT itself (Fluck et al., 2016). In this sense, Furber (2012) observed that CT allows individuals to recognize computational aspects in the world around us, and to apply computational tools and techniques to improve our reasoning and our understanding of the natural and artificial processes at work in our everyday context. Grover and Pea (2013) point out that computation is a human activity in which abstraction helps us to filter information and to focus on essential aspects. As such, CT helps in the creation of knowledge, and computer programming is essentially a creative process. The authors also highlight that technological development and CT tend to move in tandem in the direction of improved educational results, with CT promoting innovation by default. Other authors, on the contrary, urge caution in relating such a broad range of educational benefits to CT, highlighting a lack of sufficient empirical research in this field to link CT with actual learning. A recent systematic review by Kalelio lu et al. (2016) concluded that the literature on computational thinking is "at an early stage of maturity", in particular regarding research design (p. 591). However, whatever the expected benefits and real impact that could be attributed to CT, the reality is that many education systems are including CT in their official curriculum and/or introducing CT in practice in the guise of a range of different educational approaches from programming to robotics, among others. Countries such as Canada, the United Kingdom, Finland and Australia are just a few examples of this trend (Acevedo Borrega, 2016; Bocconi, Chioccariello, Dettori, Ferrari, \& Engelhardt, 2016a).

One of the problems identified in the studies mentioned above is the broad range of definitions used for CT. In fact, there is no consensus in the literature as to what elements or components define CT. Many definitions would list among the intrinsic elements of CT characteristics such as abstraction, generalization, decomposition, algorithmic thinking and depuration (Angeli et al., 2016). Other authors would add automation (Bocconi et al., 2016a), the collection and processing of information and its representation (Barr \& Stephenson, 2011), ascending and descending analysis, heuristics, divergent thinking, recursivity, iteration, approximation and meta-cognition (Zapata-Ros, 2015). Additionally, attitudinal elements like confidence, perseverance and collaboration are connected to CT (Bocconi, Chioccariello, Dettori, Ferrari et al, 2016b).

One of the problems with this lack of a complete, consensus-based definition of CT is that it can lead to educational approaches that adopt an incomplete view of the concept. For instance, if one considers the elements of CT to be the five elements initially suggested by Wing $(2016,2010)$ and developed by Angeli (2016) (see above), it is understandable why CT in the educational system has been mostly limited to experiences in robotics and programming (Furber, 2012; Yadav, Gretta, Good, \& Mclean, 2017; Yadav, Hong, \& Stephenson, 2016). This is because it is generally (but wrongly) assumed that only in learning situations involving programming or robotics can CT be acquired (Yadav et al., 2017). It is worth noting that the relationship between the CT and robotics is not biunivocal, since robotics does not necessarily guarantee the development of CT, and CT can be acquired by means other than robotics (Bocconi, et al, 2016b; Voogt, Fisser, Good, Mishra, \& Yadav, 2015, Yadav et al., 2017). Something similar happens with digital competence, which is usually strongly linked to the development of CT, especially if we consider the conceptual proposals of Barr and Stephenson (2011) or Zapata-Ros (2015). However, the relationship between the two areas is not univocal: digital competence does not necessarily influence CT, in the same way that one can acquire CT without also enhancing one's digital competence. Therefore, although learning computer programming languages and technologies can stimulate the acquisition of CT, this is not direct, nor does it occur by default. On the contrary, learning of CT must be specifically planned with didactic strategies that take into account means of developing it. As a result, while it is common to think that CT should be a specific subject in the curriculum (and, indeed, this has been the case in most of the national educational contexts mentioned above (Brennan \& Resnick, 2012), there are authors who believe that CT is more effective when it is integrated into other subjects' curricula as a learning strategy rather than treated as a subject in its own right (Morreale Jiménez, Goski, \& Stewart-Gardiner, 2012; Bocconi et al., 2016a).

In recent years, there have been growing demands for research identifying the best existing (or potential) methodologies to ensure that students improve their CT (Adell, Esteve-Mon, Llopis Nebot, \& Valdeolivas Novella, 2017). Scholars have called for a multidisci- 
plinary integration of CT that goes beyond restrictive approaches like those limited to programming (Bocconi et al., 2016). There are also pedagogical models like the CTPF (Computational Thinking Pedagogical Framework) (Kotsopoulos et al., 2017), which proposes the use of a sequence of phases for CT teaching and learning. These approaches use a series of learning modules which can be applied in chronological sequence, corresponding to a series of phases. The analogic programming phase (unplugged) is followed by phases of un-guided experimentation (tinkering), scheduled experimentation, projects and a final integrative phase (remixing). Undoubtedly, this is a promising theoretical model for CT instruction. In order to arrive at practical applications, it is very important to advance in curricular design and research to aimed at uncovering an optimal CT learning sequence (Adell Segura et al, 2017; Grover \& Pea, 2013).

\section{Computational thinking and teacher education}

Despite the many different definitions of CT (see, for example, Moreno-León, Robles, Román-González \& Rodríguez, 2019) and the lack of sufficient empirical research on instructional design and impact, there is consensus in the literature that the acquisition of CT by students is neither spontaneous nor guaranteed by the participation in robotics or programming activities. Of course, an initial pre-requisite for students to learn CT is that their teachers are familiar not only with CT general, but also with what CT concepts should be taught and how and why to teach them. That inescapably leads us to the role of CT in teacher training.

According to the literature, although many efforts have been made in the area of CT teacher education (Morreale et al., 2012; Morreale \& Joiner, 2011), the training of in-service teachers has been mostly instrumental, that is, exclusively focused on programming (Bustillo \& Garaizar, 2015). While many teachers already use CT strategies without being aware of it (Barr \& Stephenson, 2011; Yadav et al, 2017), their competence for CT teaching cannot be assumed. As a result, the impact of this training on the implementation of CT strategies in compulsory education classrooms of has been rather limited. In this sense, recent proposals focus first on offering CT training to teachers themselves and second on the pedagogical models associated with CT (Morreale et al., 2012).

Taking into account that an initial condition for CT instruction is that teachers have acquired the minimum technical skills as users (Adell, Segura et al., 2017), CT training for teachers is necessary, because most of our future teachers have not been previously trained in CT. Most have little or no experience in robotics or programming (Bustillo Bayón, 2015). In this sense, a first level of training must ensure the acquisition of the instrumental domain tools or languages that are to be used, that is, a training that ensures teachers' CT competence.
Teachers, however, not only need to be competent in CT, but in CT instructional design and curriculum implementation as well. In other words, they must be able to use educational strategies that allow students to gain competence in CT (Prieto-Rodríguez \& Berretta, 2014). At the moment, different models of training in Didactics of CT are also emerging. Broadly speaking, these proposals seek to apply the general ideas of the TPACK model to the CT field (Mishra \& Koehler, 2006, 2008). These approaches synthetically indicate that any training plan for teachers should ensure (1) that the teacher identifies clearly which projects can accommodate situations of CT learning, (2) that the teacher is capable of identifying which technologies are best suited to these projects, and (3) that the teacher identifies the opportunities to transform the symbiosis between these projects and these technologies in CT learning. Most of the identified proposals emphasize active teacher training and give special attention to the technical part of their training (Bustillo Bayón, 2015;. Morreale et al, 2012; Yadav et al, 2017). From our point of view, there is still a lot of work to do on teacher education with regard to $\mathrm{CT}$.

The potential role of CT in pre-service teachers' education has received even less attention. Indeed, it is rare to find teacher training programmes that incorporate CT (Yadav et al., 2017). The few experiences in this regard that have been documented indicate that the scattered efforts that have been made (and even specific, isolated actions) have produced very interesting results. For example, Bustillo (2015) points out that the improvement in attitudes is almost constant in the teacher training experiences (in-service and pre-service), and many observers have also pointed out that such interventions tend to help to clarify the concept of CT and combat the mistakes in its interpretation (Morreale \& Joiner, 2011). As for the impact of this training, although the literature is not yet abundant due in part to the relative novelty of this area of knowledge, the prevailing idea is that the participating teachers quickly improve their CT competence and their abilities to design CT learning strategies (Morreale et al., 2012). Studies have also shown that sharing best practices tends to be a helpful stimulus for teachers to make the leap to practice (Ertmer \& Ottenbreit-Leftwich, 2010) and that the majority of teachers participating in training sessions (especially those with a special focus on didactics) end up applying CT strategies in their own teaching practice, albeit superficially (Dapozo et al., 2016).

\section{Computational thinking in practice: the Catalan context}

In our context in Catalonia, like in many other places in the Western world, there are more and more schools and educational initiatives related to educational robotics and computer programming. As we have published elsewhere, common initiatives in this field are based on the use of Lego-Mindstorms educational kits or Lego We-DO, kindergarten robots such as Bee-Bot, the 
Scratch programming platform or its earlier-ages version ScratchJR, and panels of Arduino microcontrollers (Estebanell Minguell, Gonzalez Martinez, Peracaula Bosch, \& Lopez Simon, 2017). In addition, as was also pointed out above, several local and national initiatives have been undertaken with the aim of promoting computational thinking, including many extracurricular coding programmes and clubs as well as activities organized by museums, European projects, foundations, administrations, enterprises and networks, among others. Some activities are also taking place in schools, but it is not the case that most teachers feel sufficiently prepared to face this challenge. A desirable first step would be to ensure that new teachers enter the profession with the CT competence and professional capacities they need to engage in successful CT instruction. From a constructivist viewpoint of teacher development, the quest for this outcome should involve identifying and then reorganising pre-service teacher training, starting with an examination of their initial knowledge, beliefs and attitudes with respect to CT. The first step, then, would be to determine what our future teachers understand by CT. Do they really know what it involves? Are they able to distinguish CT from robotics or from programming? What objectives do they believe are pursued by CT? The aim of the first phase of the PECOFIM (Computational Thinking Teacher Training project funded by AGAUR-Generalitat de Catalunya, https://pecofim.wixsite.com/ pecofim) is to explore these concerns. More specifically, this article uses survey data to analyse the initial concepts and attitudes with respect to CT held by preservice teachers and the relationships established between their knowledge, their attitudes and their expectations in this regard.

\section{Method}

This research is based on a descriptive analysis of qualitative and quantitative data gathered during the spring and autumn semesters of 2017 via an ad hoc questionnaire expressly designed for this innovation experience, in which pre-service teachers are to be trained in CT education in different courses throughout their degree. The questionnaire will be repeated in future school-years in different stages and iterations of the students' training. The choice of this technique fits within the overall strategy of the innovation project, founded on the model of research-based design (Plomp $\&$ Nieven, 2010). In the initial phases of this project, it was determined that a questionnaire like the one that was created here could be an effective way to collect contextual information for the initial analysis of the situation. Based on these considerations, the questionnaire is intended to explore the following research questions and sub-questions:

RQ1. What do pre-service teachers know about CT prior to being trained in it?

RQ1.1. What do teachers in training know about CT?
RQ1.2. What elements of CT do pre-service teachers recognize?

RQ2. What are their attitudes and expectations with regard to CT?

RQ3. What relationships are there between their knowledge and their expectations with respect to CT?

As introduced earlier, based on the research questions, we designed an ad hoc questionnaire of an investigative nature, with the following structure:

A) Profile data

B) Concept of Computational Thinking

(1) An open question to find out how the pre-service teachers define CT (serving RQ1.1)

(2) A number of questions about the importance of CT elements in opposition to other educational goals (like digital competence), the identification of CT elements among other educational elements (like digital competence or informational literacy) and the perceived education goals CT can be used to pursue (serving RQ1.2)

C) Attitudes and expectations towards the educational implementation of CT activities (serving RQ2).

This questionnaire was developed by members of the research group and was reviewed and validated by the group during a research meeting. Before it was administered online to the participants, a pilot test was conducted with target subjects.

The sample was composed of a total of 193 first-year students enrolled in the Primary and Early Childhood Education Degrees at the University of Girona (Spain). The synthetic profile of the respondents was: $23.3 \%$ were men, $76.7 \%$ were women; $39.9 \%$ said they had participated in experiences related to CT, and $60.1 \%$ said they had no previous experience. Of those who indicated that they had participated in training experiences related to CT, $9.8 \%$ had done so at the stage of primary education, $25.9 \%$ during compulsory secondary education and $4.2 \%$ as extracurricular activities. It is worth noting here that there are possible biases derived from the wording of the question itself, which avoided the undesired conflation CT and robotics/ programming. In this sense, there may be students who may have participated in activities related to robotics and educational programming but were not aware that these activities are linked to CT.

Qualitative data were encoded from a soft categorical code-book created in a bottom-up fashion using content and discourse analysis. The quantitative data were cleansed, tabulated and analysed with basic descriptive statistics (ANOVA test for levels of significance when we worked with the sample set, which revealed a normal distribution; Chi-square test for significance grades when we worked with fractions of the sample whose distribution was not normal). When appropriate, a cluster analysis was also carried out, using the dendrogram feature of SPSS, in order to identify free association patterns in the RQ1.2 data (Vilà Baños, Rubio Hurtado, Berlanga Silvente \& Torrado Fonseca, 2014). 


\section{Results}

RQ1.1: What do teachers in training know about CT?

We consider that a pre-service teacher is familiar with the concept when his or her definition has a meaning similar to the definitions in the literature, or when it lists the basic elements considered characteristic of computational thinking.

Partial knowledge, for example, would be found in responses in which the computational thinking is related only with technology, although some elements are correctly identified.

Some examples of the students' answers, ordered from greater to lesser knowledge of the concept of CT are:

"The ability to isolate problems, identify them, solve them and be able to generalize with them later".

"A person uses computational thinking by solving a task or problem through a set of sequences. The simile would be the steps that a computer engineer follows to build a computer program. Computational thinking favours problem solving, encourages creativity and works on different curricular competences (STEAM)."

"It would be the resolution of problems of daily life based on scientific thought."

"It is the kind of thinking that considers technology as a tool. It is shaped by computer programming and ICT"

"To solve the problems that may arise through new technologies"

"To have knowledge about computers"

As shown in Figure 1, we can see that the bulk of the sample is not able to produce an acceptable definition of CT (78\% produced an inadequate answer based on Estebanell et al. 2018), and 8\% explicitly indicated that they did not know what CT was). On the other hand, only $2 \%$ offered a definition that we could consider acceptable, and $12 \%$, despite the incompleteness of their definitions, were able to identify important elements of CT.

Regarding the potential impact of pre-service teachers' previous educational experience on their familiarity with CT, in Table 1 we can see that there is a significant difference between the knowledge of the concept of CT of those who were learning about it for the first time and with those with some previous experience $(\mathrm{p}<.05)$. However, and contrary to what would be expected, those who do have previous experience of CT produce slightly more inadequate definitions of CT than those who do not. As a final note, it is necessary to document that no other significant difference as a function of the other variables (gender or academic degree) was found.

In their definitions of CT, pre-service teachers mentioned a number of different aspects related with the concept. As seen in Figure 2, the most frequently mentioned aspects were programming (25\%) and ICTs (or technology in a broader sense, with $28 \%$ ). Less often

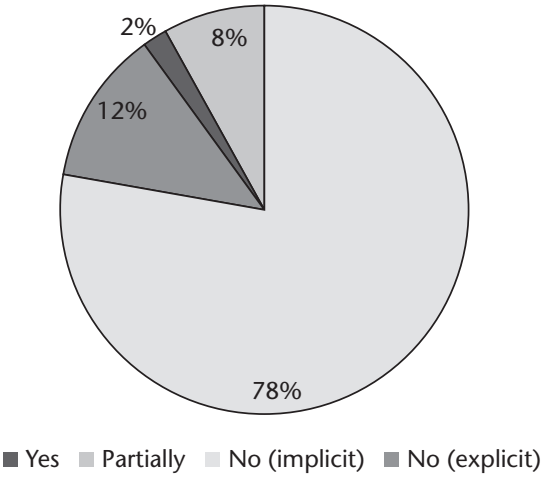

Figure 1. Knowledge of the concept of CT.

Table 1. Differences in the knowledge of the concept of CT as a function of previous experience, in \% (chi-square 0.008)

\begin{tabular}{lllc}
\hline & $\begin{array}{l}\text { Without previous } \\
\text { experience }\end{array}$ & $\begin{array}{l}\text { With previous } \\
\text { experience }\end{array}$ & Total \\
\hline $\begin{array}{l}\text { With knowledge of } \\
\text { the concept of CT }\end{array}$ & 1.7 & 1.3 & 1.6 \\
\hline $\begin{array}{l}\text { With partial knowledge } \\
\text { of the concept of CT }\end{array}$ & 6.9 & 10.4 & 8.3 \\
\hline $\begin{array}{l}\text { Without knowledge } \\
\text { of the concept of CT }\end{array}$ & 72.4 & 85.7 & 77.7 \\
$\begin{array}{l}\text { State they do not know the19.0 } \\
\text { concept of CT }\end{array}$ & 100 & 2.6 & 12.4 \\
\hline TOTAL & 100 & 100 \\
\hline
\end{tabular}

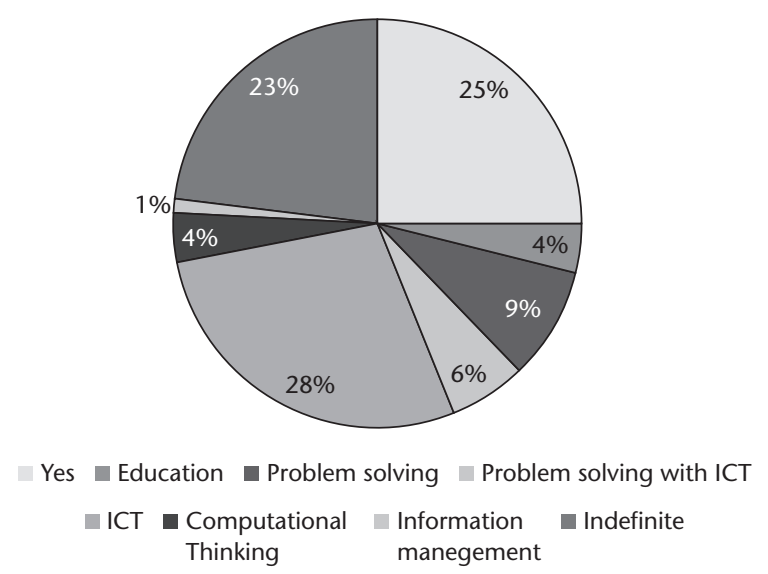

Figure 2. Assignment of the concept to CT.

mentioned but also noteworthy characteristics are problem solving in general, or problem solving with ICTs (with 9\% and 6\%, respectively).

Again, we can see what differences appear as a function of variables such as prior experience. Table 2 shows that the differences are significant $(\mathrm{p}<.05)$, indicating that previous experience with CT is strongly related with a view of CT that is more biased towards programming and technological elements, which is in agreement with results that show that most CT activities are of this nature. This fact also might explain why preservice teachers with previous experience produced slightly worse definitions of CT than those who lacked such experience (Table 1), as the former group were more oriented towards a biased definition. Despite the 
Table 2. Differences in allocation of field to the concept of CT as a function of previous experience, in \% (0.024 Chi-square)

\begin{tabular}{llll}
\hline & $\begin{array}{l}\text { Without previous } \\
\text { experience }\end{array}$ & $\begin{array}{l}\text { With previous } \\
\text { experience }\end{array}$ & Total \\
\hline Programming & 22.4 & 28.6 & 24.9 \\
\hline Educational elements & 4.3 & 2.6 & 3.6 \\
\hline Problem solving & 6.9 & 11.7 & 8.8 \\
\hline ICT & 26.7 & 31.2 & 28.5 \\
\hline CT & 4.3 & 2.6 & 3.6 \\
\hline Indefinite & 31 & 10.4 & 22.8 \\
\hline Problem solving with ICT & 3.4 & 10.4 & 6.2 \\
\hline Information management & 0.9 & 2.6 & 1.6 \\
\hline
\end{tabular}

link between these programming or technology-based previous experiences and biased definitions of CT, this prior participation in CT educational activities does have more beneficial implications, such as a greater likelihood to associate CT with problem solving (with or without ICT) and less of a tendency to offer indefinite answers. However, the lack of reflective, comprehensive, well-defined educational activities to develop CT as a cross-cutting competence means that only the most evident, instrumental elements of CT emerge in the answers. This points to the importance of including theoretical reflections and practical experience with these broader definitions of CT in our teacher education courses, going beyond coding or robotics in the strictest sense.

\section{RQ1.2 What elements of CT do pre-service teachers recognize?}

One could argue that the lack of proper definitions and elaborations on the concept of CT is partly a product of the always demanding task of asking someone to define something out of the blue. In this sense, our questionnaire also included a question in which pre- service teachers were only asked to recognize and select certain elements from a list that included both CT and non-CT elements. As seen in Figure 3, we asked respondents about specific aspects of digital competence (risk management in the use of ICT-related information processes, choosing the best technology among the available ones in relation to a particular task or digital communication), related to other transversal skills (finding creative solutions, autonomy and coordination) and, finally, more restrictive elements of the concept of CT (testing, segmentation tasks and establishing rules). As can be seen, the identification of phenomena connected with CT is not particularly successful: a large proportion of the students incorrectly listed "choosing the best technology", "processes related to information" and "management of risks derived from the use of ICT" as elements of CT. On the other hand, two of the elements that are indeed at the core of CT (testing and rules) were among the least frequently chosen. We can conclude, therefore, that pre-service primary school teachers have great difficulty in identifying many important elements of CT. There were no gender or previous experience effects regarding this difficulty. However, having some knowledge, even if it is partial, of the concept of CT is correlated with the recognition of some CT elements like segmentation and testing (with chi-square results of 0.005 and 0.007 , respectively), although not with "the search for solutions". This leads us to think that, to some extent, this whole diagnosis is consistent.

As a summary of these data, we can see that the elements that were most often selected as part of CT are (depicted with longer blue areas on the graph) are those that correspond to elements of Digital Competence (DC). On the other hand, items that are indeed part of CT are shown in the central area (i.e. they are not especially likely to be correctly identified). From

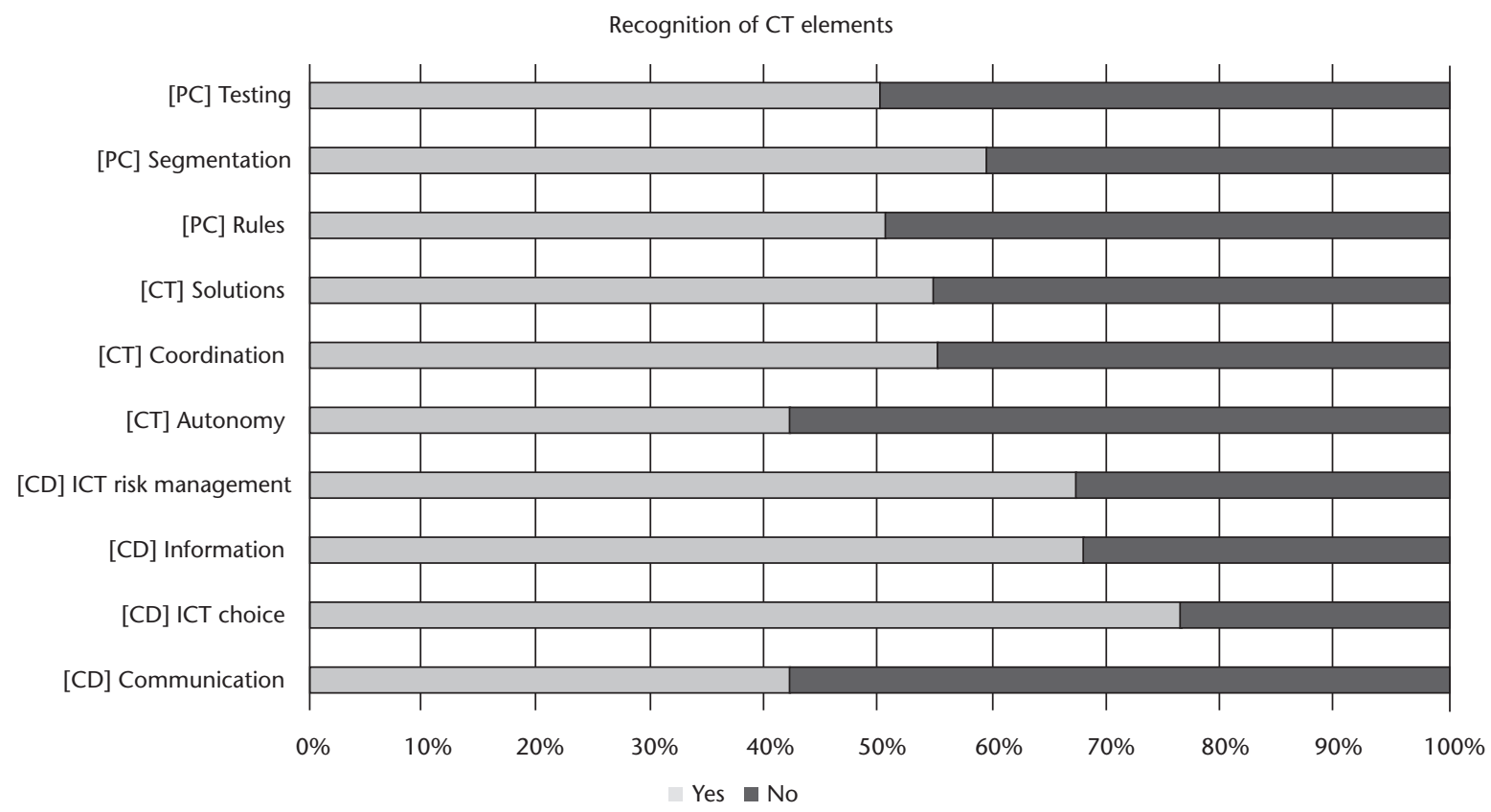

Figure 3. Recognition of CT elements as opposed to other elements of Digital Competence or other skills. 
there, we can add that a hierarchical cluster analysis does not provide any special information regarding patterns of choice of these elements. It could be that those informants who correctly selected these elements of CT did so in a way that shows their special knowledge in this regard. However, the clusters generated by the model are scattered and difficult to interpret in this sense, because none of the conglomerates (small conglomerates in relation to the sign, by the way) coincides with clarity with the positive grouping of the CT elements subject to question.

\section{RQ2. What are pre-service teachers' attitudes towards CT?}

In addition to their initial knowledge of CT, the expectations and attitudes of pre-service teachers towards CT represent an important variable affecting their future learning in the area. For this analysis, answers from pre-service teachers were grouped into three categories: the importance given to the elements of CT as opposed to other educational elements, the expectations deposited in CT, and the attitudes regarding the integration of robotics and programming experiences into educational practice. Regarding the first point, in Figure 4 we can see that the elements that are most important from an educational point of view are communication, coordination, autonomy and management of the risks involved in the use of ICT. In contrast, CT elements were perceived as the least important from and educational point of view, although the perception of these elements was positive. We can analyses this from a perspective that distinguishes between the more central elements of CT the other elements that are often associated with CT but are not exclusive to the field. This shows that when it comes to CT, pre-service teachers often must face the usual tension between a narrower focus on developing specific competences in a certain area or field and a broader focus on more transversal competences. Nonetheless, in actual practice it is not so necessary to choose (one can prepare activities to acquire competence in testing while also encouraging autonomy and creativity). While transversal competences are undoubtedly of vital importance, an inability to identify and select the specific competences that apply to a particular knowledge area detracts from the quality of the learning in that area. From the data analysis, however, we cannot go further than saying that, in an initial diagnosis, the specific elements of CT got less attention the more transversal aspects. It would be interesting to revisit these issues in future phases of research to see how students' selection of elements may or may not evolve after conscious exposure to CT concepts during the training process.

Regarding the expectations of pre-service teachers with respect to CT, shown in Figure 5, it is evident that the participants viewed CT as motivating and felt that it enables team work and DC. However, they did not consider it to have a degree of high potential in terms of inspiring scientific vocations or developing other specific scientific competences. That is, before acquiring a more comprehensive and didactical view of CT for teaching, pre-service teachers do not perceive the connections between CT and other fields. In addition, and elaborating from previous answers, programming is not a very highly rated competence here. This makes us think that pre-service teachers' ideas of CT are more related with technology per se and with the ludic / motivational component which is generally present in prototypical "fun" robotics activities than in competences specific to CT. In our view, this is related with the quality and approach of common, perhaps proto-

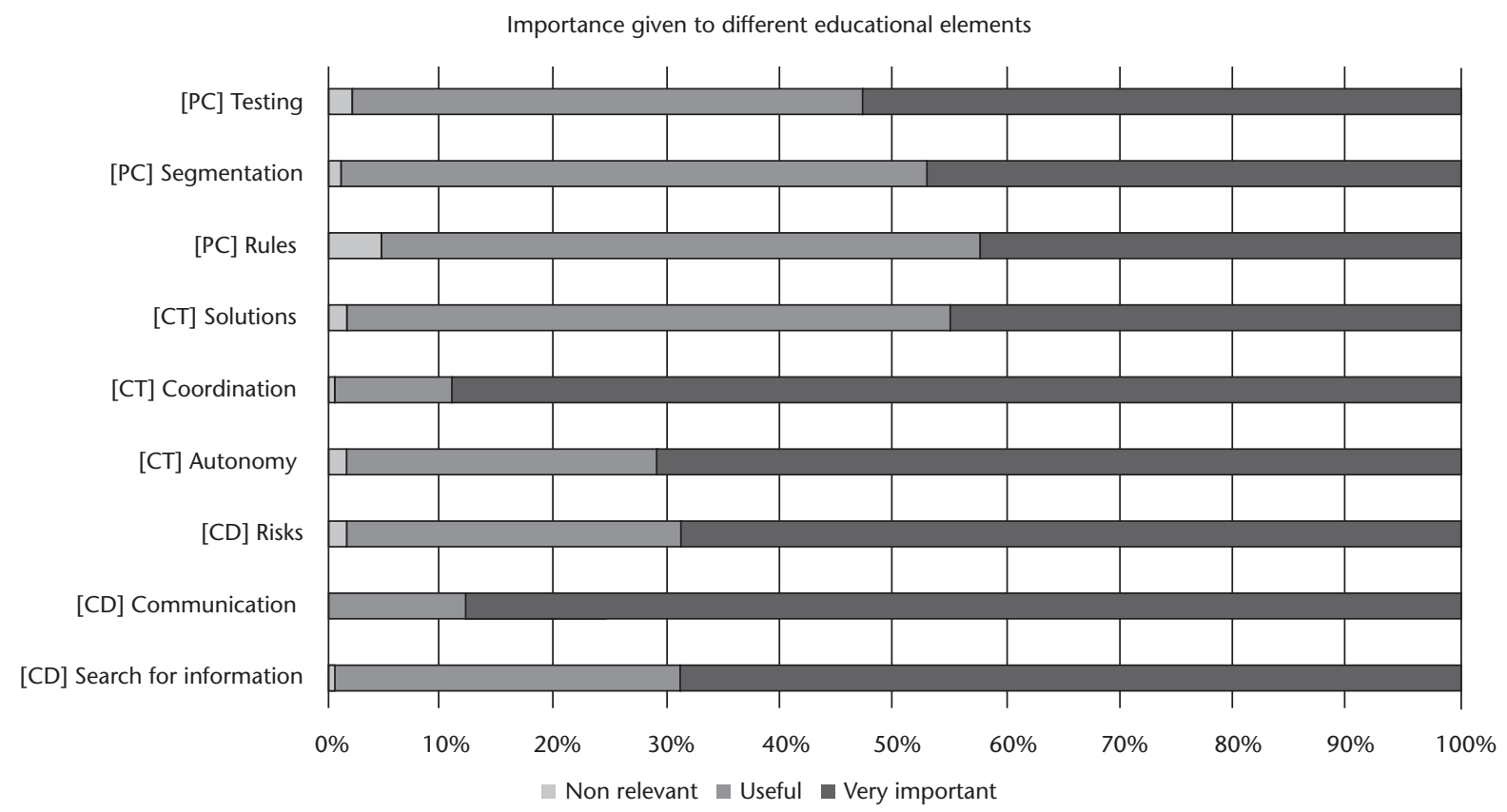

Figure 4. Emphasis given to elements of CT as opposed to other elements of DC or other skills. 


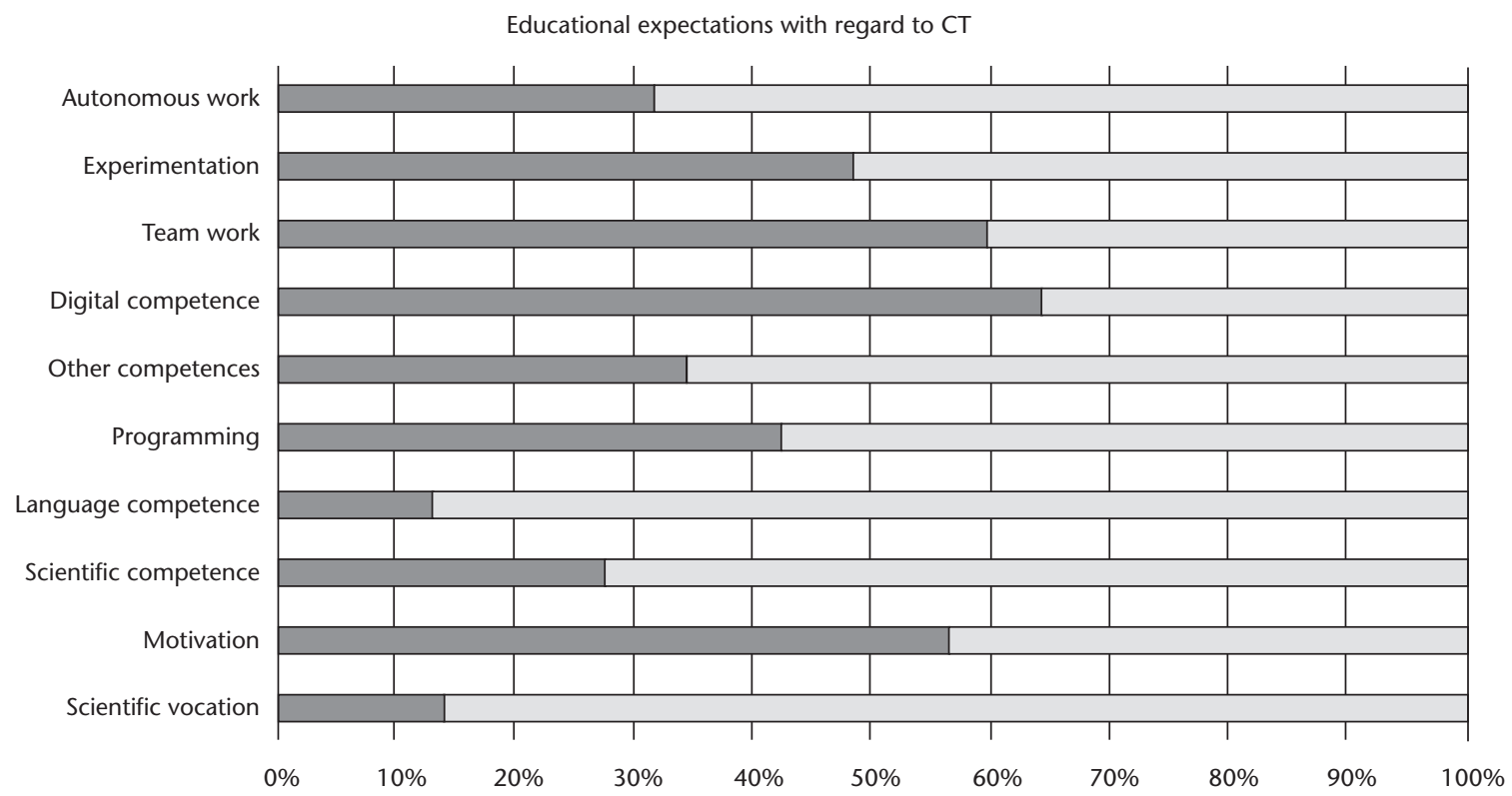

Figure 5. Significance of CT for different educational goals (expectations).

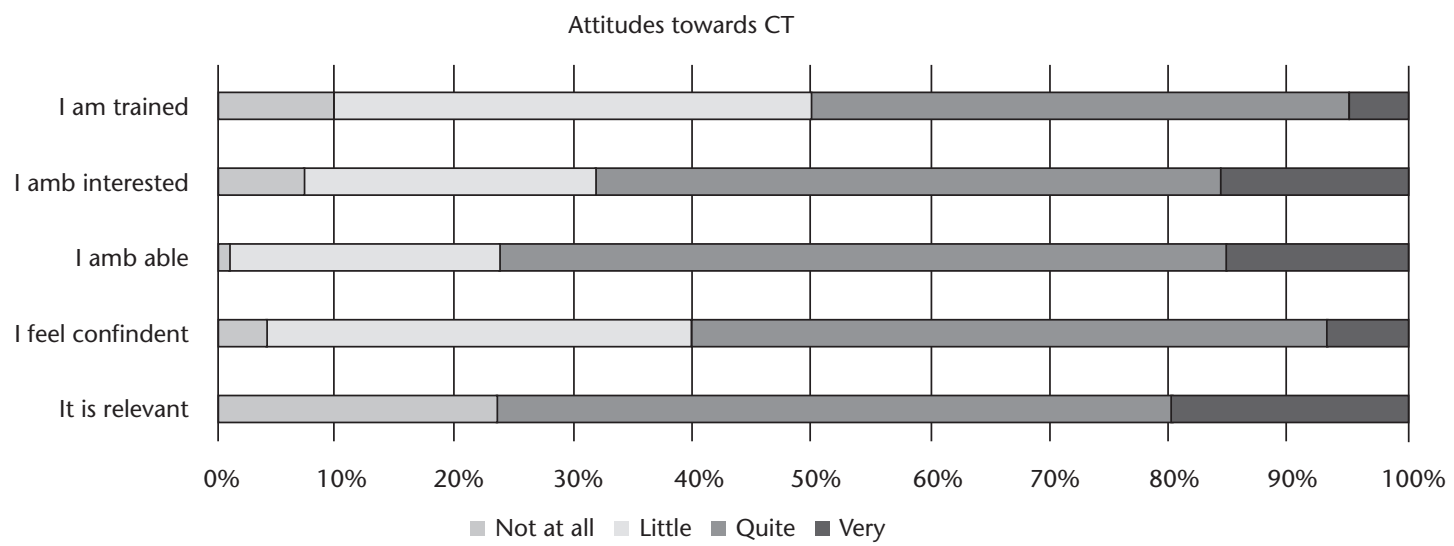

Figure 6. Attitudes toward robotics and educational programming.

typical CT activities, in addition to the fact that they have never before addressed CT in a pedagogical context and with a teaching focus

\section{$R Q 3$. What relationships are there between their knowledge of CT and their expectations?}

In our sample, there are not significant differences that allow us to uncover interesting profiles in pre-service teachers' relation to CT. The only statistically significant difference (chi-square below 0.05) was found when we crossed CT previous experience with motivation and DC. This difference, however, is the opposite of what could be expected and signals an important fact that we should take into account: the importance given to CT is not directly associated with actual prior experience with CT educational activities, but with beliefs about what these activities are like. In this sense, pre-service teachers who report having no previous CT experience are more likely to think that CT will help them improve DC and that it can be motivating.
Finally, as shown in Figure 6, we can analyse attitudes toward robotics and programming themselves. In this sense, we see that these attitudes are positive, but not enthusiastic. The students are interested and view themselves as able to take on the challenge, but they are not particularly confident or informed about what this entails. Above all, they consider it important to take advantage of this opportunity as future teachers, which is perhaps the most notable finding regarding their attitudes, as this question not only had the highest positive values, but it received no negative responses. Finally, there were no significant differences in terms of attitudes either: i.e., those who knew what CT is and those who had had previous training did not feel better formed or more interested, nor did they believe they were more or more able. However, there was a significant difference (Chi-square of 0.031) in the relevance attributed to robotics between those who knew what CT was and those who did not: those who were familiar with CT were more likely to think it was relevant. 


\section{Discussion}

The study described in this paper is an attempt to answer two important questions regarding CT and preservice teachers: (1) What knowledge do teachers have about the concept of CT? and (2) What are their attitudes and expectations in this regard.

Regarding the first question, we saw that different authors had already put the focus on teachers' low degree competence in applying computational thinking strategies (Yadav et al, 2017.), while other researchers have shown that these skills are often purely instrumental (linked to programming, but not to the teaching of CT itself) (Bustillo Bayón, 2015). Thus, our research focuses on a necessary initial step, investigating pre-service teachers' understanding of the concept of CT before they study CT didactics. Our data confirm that the pre-service teachers surveyed were largely unfamiliar with CT. This applies both to those who had had previous CT experience in formal and informal educational situations and those who had not. We had already sensed this in earlier phases of this research (González-Martínez, Estebanell, \& Peracaula-Bosch, 2018), but now it is clearly shown and coincides with what was expected in light of the literature (Morreale et al., 2012, among others).

It is also interesting to see that this lack of knowledge is in some way predictable. For example, Bocconi et al. (2016a) or Voogt et al. (2015) found that one of the challenges facing teacher training in CT has to do with undoing erroneous conceptual associations, or at least, debunking assumptions about biunivocal relationships like the ones sometimes imagined between CT and DC (which do not guarantee one another) and between CT and coding (as CT does not necessarily include computer programming, and programming on its own does not guarantee the development of CT). In fact, our data confirms that these associations exist, as the definitions offered by teachers in training lean toward conceptual approaches that are closer to DC than to CT, and when they are asked to identify possible elements of CT, they are more likely to choose elements characteristic of DC. Moreover, this is independent of whether or not they have had CT experience in previous educational stages, as the underlying concepts attributed to CT are hardly different in students who have experience and those who do not. At the same time, those who have had previous experience seem to prefer definitions of CT associated with programming or robotics. This may be further confirmation of what Bustillo Bayón (2015) wrote in relation to the limited and exclusively instrumental training of teachers, which leads them to design educational activities (which our future teachers with previous experience had completed as students) with approaches more constrained to coding and less likely to embrace an integral experience of CT. The picture, in any case, is diverse, heterogeneous. There are patterns, as we have described, but different conceptual realities, in which technology perhaps commonly takes prece- dence and computational processes tend to be dismissed.

Worthy of mention are the expectations and attitudes of these teachers in training towards CT and its educational potential. They are generally positive. This is also linked to the feeling of novelty surrounding CT in our times (European Commission/EACEA/Eurydice, 2012;) Flück et al., 2016; Bocconi et al., 2017; Estebanell et al., 2017; González-Martínez et al. 2018). Regardless of whether they had had previous experience of CT, pre-service primary school teachers found it to be relevant and believed that it could contribute to the acquisition of different educational objectives. They see themselves as able to lead educational interventions in this regard. However, they know they are not trained enough in this field, and therefore they are not confident in their ability to do so at this time, which is a quite reasonable position in light of their status as future professionals who have yet to receive specific training in this area. However, their expectations are limited to the school environment and do not encompass broader objectives such as promoting scientific vocations. A number of authors (European Commission / EACEA / Eurydice, 2012;. Bocconi et al, 2016A) and policy makers have emphasised that CT should be integrated into the formal education system to ensure that an adequate number of students, especially females, choose careers in science). That's something that, today, is not at the forefront of pre-service teachers' expectations and which should be addressed in CT teacher education.

Finally, these data suggest that intervention in teacher training is necessary, not only in terms of technological aspects (the necessary literacy) and teaching approaches (how to design CT learning experiences), but also to reinforce conceptual understanding. Before training teachers in the use of technologies required for the application of CT in the classroom and the teaching aspects involved in it, we must first ensure that they know also what they mean when they refer to CT and what its implications and its educational potential are. This has been one of the limitations of our study: a greater consensus on the definition and applicability framework of CT would help to focus more closely on pinpointing the CT indicators that informants were able to correctly identify. The study would also have benefitted from including a broader range of Universities in different territories with underlying variations in their pre-University educational systems. Nevertheless, this research establishes the starting point of a prospective longitudinal study aimed at identifying a framework for CT didactics that would enable preservice teachers to develop skills that promote the use of CT at different educational levels as a significant learning tool.

\section{Conflict of interest statement}

The authors declare that there is no conflict of interest relevant to this study. 


\section{Founding}

This research was supported by a grant from AGAUR, Agència de Gestió d'Ajuts Universitaris i de Recerca. Departament d'Economia i Coneixement. Generalitat de Catalunya. Ref. Number: 2015 ARMIF 00031

\section{References}

Acevedo Borrega, J. (2016). El pensamiento computacional en la educación obligatoria. Una revisión sistemática de la literatura. Universidad de Extremadura.

Adell, J., Esteve-Mon, F. M., Llopis Nebot, M. Á., \& Valdeolivas Novella, M. G. (2017). El Pensamiento Computacional en la formación inicial del profesorado de Infantil y Primaria. In Actas de las XXV Jornadas Universitarias de Tecnología Educativa (pp. 1-7). Burgos: Red Universitaria de Tecnología Educativa.

Angeli, C., \& Valanides, N. (2005). Preservice elementary teachers as information and communication technology designers: An instructional systems design model based on an expanded view of. Journal of Computer Assisted Learning, 1(4), 292-302. Retrieved from http://onlinelibrary.wiley.com/doi/10.1111/ j.1365-2729.2005.00135.x/full

Angeli, C., Voogt, J., Fluck, A., Webb, M., Cox, M., Malyn-Smith, J., \& Zagami, J. (2016). A K-6 Computational Thinking Curriculum Framework: Implications for Teacher Knowledge. Educational Technology \& Society, 19(3), 47-57.

Barr, V., \& Stephenson, C. (2011). Bringing Computational thinking to K-12: What is involved and qhat is the role of the computer science education community? ACM Inroads, 2(1), 48-54. https://doi. org/10.1145/1929887.1929905

Bocconi, S., Chioccariello, A., Dettori, G., Ferrari, A., \& Engelhardt, K. (2016a). El Pensamiento Computacional en la Enseñanza Obligatoria (Computhink). Implicaciones para la política y la práctica. Developing Computational Thinking in Compulsory Education. Implications for policy and practice. https://doi. org/10.2791/792158

Bocconi, S., Chioccariello, A., Dettori, G., Ferrari, A., Engelhardt, K., Kampylis, P., \& Punie, Y. (2016b). Developing Computational Thinking : Approaches and Orientations in K-12 Education. In Proceedings of the EdMedia 2016 Conference (pp. 1-7). Vancouver, BC, Canada: EdMedia.

Brennan, K., \& Resnick, M. (2012). New frameworks for studying and assessing the development of computational thinking. In Annual American Educational Research Association meeting (pp. 1-25). Vancouver, BC, Canada. Retrieved from http://web.media.mit. edu/ kbrennan/files/Brennan_Resnick_AERA2012_ CT.pdf

Bustillo Bayón, J. (2015). Formación del profesorado con scratch: análisis de la escasa incidencia en el aula. Opción, 31(1), 164-182. Retrieved from http://www. redalyc.org/pdf/310/31043005010.pdf

Bustillo, J., \& Garaizar, P. (2015). Scratching the surfa- ce of digital literacy... but we need to go deeper. In Proceedings of the Frontiers in Education Conference (FIE). Madrid: IEEE. https://doi.org/10.1109/FIE. 2014.7044224

Dapozo, G., Petris, R., Greiner, C., Espíndola, M. C., Company, A. M., \& López, M. (2016). Capacitación en programación para incorporar el pensamiento computacional en las escuelas. In A. E. De Giusti, I. Sattolo, J. S. Ierache, \& P. M. Pesado (Eds.), XI Congreso de Educación en Tecnología y Tecnología en Educación (pp. 113-121). Buenos Aires (Argentina): Universidad de Morón. Retrieved from http://teyetrevista.info.unlp.edu.ar/w p - con tent / uploads/2016/08/Capacitación-en-programaciónpara-incorporar-el-pensamiento-computacional-enlas-escuelas.pdf

Ertmer, P. A., \& Ottenbreit-Leftwich, A. T. (2010). Teacher Technology Change: How Knowledge, Confidence, Beliefs, and Culture Intersect. Journal of Research on Technology in Education, 42(3), 1539-1523. https://doi.org/10.1080/15391523.2010.10782551

Estebanell Minguell, M., González Martínez, J., Peracaula Bosch, M., \& López Simó, V. (2017). About the concept of Computational Thinking and its educational potentialities by pre-service teachers. In L. López Chova, A. López Martínez, \& I. Candel Torres (Eds.), Proceedings of the 2017 EduLearn 9th International Conference on Education and New Learning Technologies (pp. 6624-6630). Barcelona: EDULEARN

European Commission/EACEA/Eurydice. (2012). Developing Key Competences at School in Europe: Challenges and Opportunities for Policy. Eurydice Report. Luxembourg: Publications Office of the European Union. https://doi.org/10.2797/93204

Fernández-Llamas, C., Conde, M. A., Rodríguez-Lera, F. J., Rodríguez-Sedano, F. J., \& García, F. (2018). May I teach you? Students' behavior when lectured by robotic vs. human teachers. Computers in Human Behavior, 80, 460-469. https://doi.org/10.1016/j.chb. 2017.09.028

Fernández-Llamas, C., Conde, M. Á., Rodríguez-Sedano, F. J., Rodríguez-Lera, F. J., \& Matellán-Olivera, V. (2017). Analysing the Computational Competences Acquired by K-12 Students When Lectured by Robotic and Human Teachers. International Journal of Social Robotics. https://doi.org/10.1007/s12369-017-0440-9

Fluck, A., Webb, M., Cox, M., Angeli, C., Malyn-smith, J., Voogt, J., \& Zagami, J. (2016). Arguing for Computer Science in the School Curriculum. Educational Technology \& Society, 19(3), 38-46.

Furber, S. (2012). Shut down or restart? The way forward for computing in UK schools. London (UK): The Royal Society.

García-Peñalvo, F. J. (2016). Presentation of the TACCLE3 Coding European Project. Salamanca. Retrieved from http://repositorio.grial.eu/handle/grial/654

García-Peñalvo, F. J., Reimann, D., Tuul, M., Rees, A. M., \& Jormanainen, I. (2016). TACCLE 3, O5: An overview of the most relevant literature on coding and computational thinking with emphasis on the relevant 
issues for teachers. Belgium. https://doi.org/10.5281/ zenodo. 165123

González-Martínez, J., Estebanell, M., \& PeracaulaBosch, M. (2018). ¿Robots o programación? El concepto de Pensamiento Computacional y los futuros maestros. EKS. Education in the Knowledge Society, 19, 29-45. https://doi.org/http://dx.doi.org/10.14201/ eks20181922945

Grover, S., \& Pea, R. (2013). Computational Thinking in K-12: A Review of the State of the Field. Educational Researcher, 42(1), 38-43. https://doi.org/10.3102/ 0013189X12463051

Kotsopoulos, D., Floyd, L., Khan, S., Namukasa, I. K., Somanath, S., Weber, J., \& Yiu, C. (2017). A Pedagogical Framework for Computational Thinking. Digital Experiences in Mathematics Education, 2017(March), 1-18. https://doi.org/10.1007/s40751-017-0031-2

Mishra, P., \& Koehler, M. J. (2006). Technological Pedagogical Content Knowledge: A Framework for Teacher Knowledge. Teachers College Record, 108(6), 1017-1054. Retrieved from http://punya.educ.msu. edu/publications/journal_articles/mishra-koehlertcr2006.pdf

Mishra, P., \& Koehler, M. J. (2008). Introducing technological pedagogical content knowledge. In A. E. R. Association (Ed.), Annual meeting of the American Educational Research Association. Annual meeting of the american educational research association.

Moreno-León, J., Robles, G., Román-González, M. y Rodríguez, J.D.(2019). Not the same: a text network analysis on computational thinking definitions to study its relationship with computer programming. RIITE. Revista Interuniversitaria de Investigación en Tecnología Educativa, 7, 26-35. Doi: http://dx.doi. org/10.6018/riite.397151

Morreale, P., \& Joiner, D. (2011). Changing Perceptions of Computer Science and Computational Thinking Among High School Teachers *. Journal of Computing Sciences in Colleges, 26(6), 71-77.

Morreale, P., Jimenez, L., Goski, C., \& Stewart-gardiner, C. (2012). Measuring the impact of computational thinking workshops on high school teachers *. Journal of Computing Sciences in Colleges, 27(6), 151-157.

Plomp, T., \& Nieveen, N. (2010). An introduction to educational design research. An Introduction to Educational Design Research. Enschede (Netherlands): SLO. Netherlands institute for curriculum development. Retrieved from http://www.slo.nl/downloads/2009/ Introduction_20to_20education_20design_20resear ch.pdf/download

Prieto-Rodriguez, E., \& Berretta, R. (2014). Digtial Technology Teachers' Perceptions of Computer Science: It is no all about programming. In IEEE (Ed.), Frontiers in Education Conference (pp. 1-5). Madrid (España): IEEE.

Vilà Baños, R., Rubio Hurtado, M. J., Berlanga Silvente, V., \& Torrado Fonseca, M. (2014). Cómo aplicar un análisis jerárquico en SPSS. Revista d'Innovació $i$ Recerca En Educació, 7(1), 113-127. https://doi.org/ 10.1344/ reire2014.7.1716.
Voogt, J., Fisser, P., Good, J., Mishra, P., \& Yadav, A. (2015). Computational thinking in compulsory education: Towards an agenda for research and practice. Education and Information Technologies, 20(4), 715728. https://doi.org/10.1007/s10639-015-9412-6

Wing, J. M. (2006). Computational Thinking. Communications of the ACM, 49(3), 33-35. https://doi.org/ 10.1145/1118178.1118215

Wing, J. M. (2010). Computational Thinking: What and Why? The Link Magazine.

Yadav, A., Gretter, S., Good, J., \& Mclean, T. (2017). Computational Thinking in Teacher Education. In M. Spector, M. J. Bishop, \& D. Ifenthaler (Eds.), Emerging Research, Practice, and Policy on Computational Thinking (pp. 205-220). Bloomington (IN, US): Springer. https://doi.org/10.1007/978-3-319-52691-1

Yadav, A., Hong, H., \& Stephenson, C. (2016). Computational Thinking for All: Pedagogical Approaches to Embedding 21st Century Problem Solving in K-12 Classrooms. TechTrends, 60(6), 565-568. https://doi. org/10.1007/s11528-016-0087-7

Zapata-Ros, M. (2015). Pensamiento computacional: Una nueva alfabetización digital. Revista de Educación a Distancia (RED), 46, 1-47. https://doi.org/10.6018/ red $/ 46 / 4$

\section{Annex. CT questionnaire structure}

\section{Initial part. Profile data}

Part 1. CT concept

1. What do you think "computational thinking" is, or what does the concept of "computational thinking" suggest to you?

2. Have you had any previous experience related to "computational thinking"?

3. Below is a list of various skills. Please indicate how important you think each is in the education of children:

- Ability to coordinate with other people and to work as part of a team. Teamwork skills, including empathy and knowledge of each member's role.

- Ability to effectively communicate orally and in writing with others when performing a task.

- Ability to divide a large task into several steps or smaller tasks and decide how best to order them (one after another, two at a time, repeating some, etc.).

- A certain degree of autonomy in solving the assigned tasks.

- Ability to choose and use the digital devices and applications (computers, web pages, apps, etc.) that may be useful to solve a task.

- Ability to seek out, contrast and select digital information considering different sources and environments.

- Ability to think of rules or conditions that simplify or facilitate the resolution of a task, such as: whenever that happens, I will take a given action. 
- Knowing how to find ways to "test" if you are getting close to the solution you are looking for when you are halfway through solving a task.

- Ability to assess the risks of using digital tools and take into account aspects such as security and identity.

- Ability to seek imaginative solutions to problems and to realise that there may be more than one solution.

4. Which of these skills do you think are related to the idea of computational thinking?

- Ability to coordinate with other people and to work as part of a team. Teamwork skills, including empathy and knowledge of each member's role.

- Ability to effectively communicate orally and in writing with others when performing a task.

- Ability to divide a large task into several steps or smaller tasks and decide how best to order them (one after another, two at a time, repeating some, etc.).

- A certain degree of autonomy in solving the assigned tasks.

- Ability to choose and use the digital devices and applications (computers, web pages, apps, etc.) that may be useful to solve a task.

- Ability to seek out, contrast and select digital information considering different sources and environments.

- Ability to think of rules or conditions that simplify or facilitate the resolution of a task, such as: whenever that happens, I will take a given action.

- Knowing how to find ways to "test" if you are getting close to the solution you are looking for when you are halfway through solving a task.

- Ability to assess the risks of using digital tools and take into account aspects such as security and identity.

- Ability to seek imaginative solutions to problems and to realise that there may be more than one solution.

5. Activities related to programming and educational robotics are being introduced and generalised in primary school curricula, as well as in non-formal educational settings. In your opinion, what do you think is the purpose of working with programming and educational robotics with primary school stu- dents?

- To encourage more children to want to work in engineering science or similar professions in the future

- To motivate students to participate in activities related to science and technology

- To learn science and mathematics curriculum content and skills

- To learn content and curricular skills in languages, humanities and social sciences

- To learn content and skills in programming and educational robotics (e.g. sequencing, algorithms, etc.)

- To learn content and skills in any subject

- To improve digital competence (knowing how to use computers safely, identifying which tools are useful in each situation)

- To acquire problem-solving strategies and develop self-confidence when dealing with complex projects with different possible solutions

- To develop transversal skills such as teamwork, communication, creativity, critical thinking, etc

- To offer a space where students can work with their hands, play and experiment

- To develop transversal skills such as initiative and autonomy

\section{Part 2. Attitudes towards CT}

Please, indicate if you agree or disagree:

6. As a future educator, I believe that we must encourage primary school students to acquire confidence and strategies for reaching and optimising solutions to complex problems of a general nature.

7. As a future educator, I believe that content linked to programming and educational robotics is relevant in compulsory education.

8. As a future educator, I am personally interested in contents linked to programming and robotics in compulsory education.

9. As a future educator, I believe that I have the necessary resources and training with respect to content linked to programming and robotics in primary education.

10. As a future educator, I feel capable of applying contents linked to programming and educational robotics in compulsory education, or I think I will feel capable of doing so once I have received the necessary training. 